\section{BMJ Paediatrics Open}

\title{
Outcomes after injury prevention counselling in a paediatric office setting: a 25-year review
}

Mark R Zonfrillo, ${ }^{1}$ Michael A Gittelman, ${ }^{2}$ Kyran P Quinlan, ${ }^{3}$ Wendy J Pomerantz ${ }^{2}$

ABSTRACT

To cite: Zonfrillo MR,
Gittelman MA, Quinlan KP, et al. Outcomes after injury prevention counselling in a paediatric office setting: a 25-year review. BMJ Paediatrics Open 2018;2:e000300. doi:10.1136/ bmjpo-2018-000300

Received 16 April 2018 Revised 18 May 2018 Accepted 24 May 2018

Check for updates

${ }^{1}$ Departments of Emergency Medicine and Pediatrics, Alpert Medical School of Brown University and Hasbro Children's Hospital, Providence, Rhode Island, USA

${ }^{2}$ Division of Emergency Medicine, Cincinnati Children's Hospital Medical Center, Cincinnati, Ohio, USA ${ }^{3}$ Department of Pediatrics, Rush University Medical Center, Chicago, Illinois, USA

Correspondence to Dr Mark R Zonfrillo; zonfrillo@ brown.edu
Objective Injury is the leading cause of death and acquired disability in children. Primary care providers routinely provide age-appropriate injury prevention (IP) counselling during healthcare visits. The objective was to review evaluations of the effectiveness of office-based paediatric IP counselling research.

Design This review identified studies from July 1991 to June 2016 of children $<5$ years and their caretakers to determine the effectiveness of office-based counselling on IP knowledge, behaviours and outcomes. Studies were included if they had: (1) an intervention for a family with a child $<5$ years of age; (2) an unintentional injury mechanism addressed during counselling; (3) one or more mechanisms recommended to be discussed for children $<5$ years in the 2007American Academy of Pediatrics Policy Statement; (4) counselling occurring in the office setting; (5) an assessment of an outcome (eg, change in knowledge, behaviour or injury occurrences); and (6) English-language publication. Study characteristics (whether the study was controlled, randomised and/ or blinded), target safety behaviours, the sample size, outcomes assessed (injuries, behaviour changes and/ or education changes) and demonstrated effects were summarised.

Results Sixteen articles met inclusion criteria. Twelve articles were randomised controlled trials, three were non-randomised trials and one was a pretest and posttest study. Fourteen articles measured a change in knowledge or reported behaviour, four included observed behaviour change and five measured change in injury outcomes. Thirteen of the 16 studies had positive effects demonstrated for certain outcomes, including for fall, poisoning, burn, fire, traffic injury and drowning prevention, while 10 showed no differences between study groups for other outcomes.

Conclusions Published outcomes-based IP-related counselling research in the primary care setting for young children is infrequent, and additional research is necessary to further describe the effectiveness of these primary prevention efforts.

\section{INTRODUCTION}

\section{Background}

Injuries continue to cause more deaths in US children than all non-communicable and infectious diseases combined. ${ }^{1}$ However, these deaths are only a small part of the problem.

\section{What is already known on this topic?}

- Primary care providers routinely provide injury prevention (IP) counselling during healthcare visits.

- One prior review in 1993 by Bass et al supported the inclusion of IP information in the paediatric primary care setting.

\section{What this study hopes to add?}

Published outcomes-based IP-related counselling for young children in the primary care setting is infrequent, but the majority of the existing studies demonstrated effectiveness.

- Further research is necessary to identify the most effective IP-related counselling in the primary care setting.

For every child that dies, approximately 25 children are hospitalised and 925 are treated in emergency departments, costing close to $\$ 300$ billion annually to US citizens. ${ }^{23}$ Injury prevention (IP) advocates continue to find ways to address this problem through new product innovations, passing legislation or making environments safer for children. Another technique is to educate families about potential age-appropriate risks so that caregivers are aware of potential hazards, and they can implement preventative strategies. Primary care providers (PCPs) have typically been tasked with screening families for risk of unintentional injuries and providing age-appropriate safety counselling. Professional societies and national task forces encourage PCPs to have these conversations at every office encounter. ${ }^{4-6}$ The American Academy of Pediatrics (AAP), in its Bright Futures recommendations for health maintenance, recommends specific topics for IP counselling at each well-child visit.

Several factors make the provision of IP counselling during well-child visits challenging. Lack of time during visits, a plethora of recommended topics that need to be 
addressed, and little training in and comfort with IP counselling have been cited as barriers. ${ }^{7-9}$ Also, with no reimbursement by insurance companies for these efforts, IP conversations may be less emphasised and given less time during visits. To overcome some of these barriers, physicians have tried providing tailored messages through cellphone applications, computerised kiosks or standardised screening tools. ${ }^{10-14}$ However, despite recommendations and because of the barriers and the inconsistent strategies employed among PCPs, IP screening and counselling is infrequently employed.

Gaps remain in our understanding about what works in an office setting to promote safe behaviours and prevent future injuries. In 1993, Bass and colleagues published a critical review of the literature regarding the effectiveness of IP counselling in the primary care setting. ${ }^{15}$ Their study used a panel from an AAP injury panel to review journal articles from May 1964 to July 1991 focused on childhood unintentional IP counselling in the primary care setting. Twenty articles met inclusion criteria, 18 of which showed positive effects of counselling, and 15 for which physicians performed counselling. They found that the published evidence at that time demonstrated that counselling resulted in greater knowledge, less risky behaviours and a reduction in injury occurrence. The purpose of this paper is to present a review of the IP literature published in the quarter century since the Bass publication in order to examine new research and

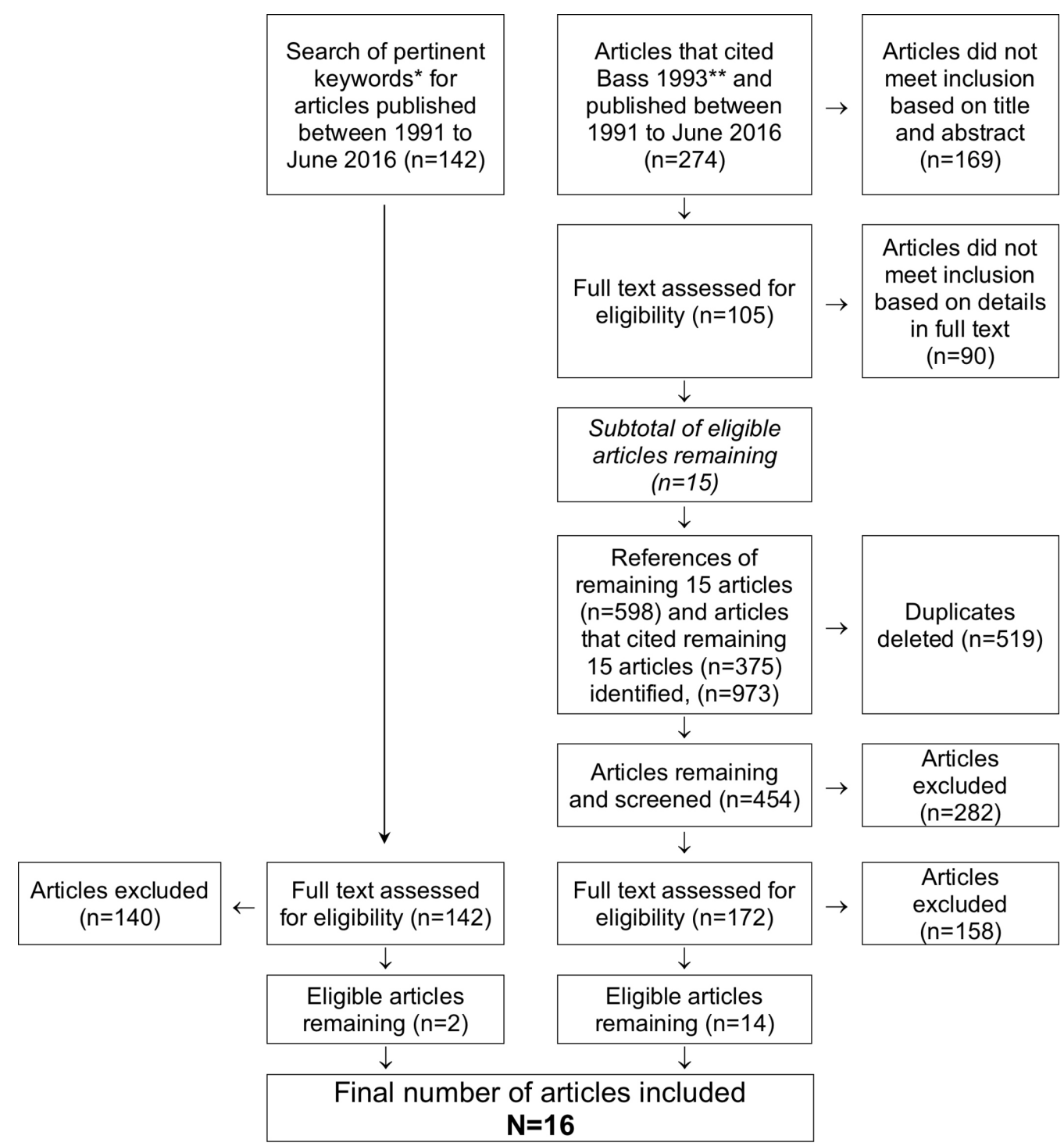

*Keyword search: (counseling or "anticipatory guidance") AND (unintentional injury or safety) AND (child or childhood or pediatric or paediatric or children) AND (office or primary care or clinic) for publications between $7 / 1 / 1991$ to $6 / 1 / 2016$

** Bass JL, Christoffel KK, Widome M, et al. Childhood injury prevention counseling in primary care settings: a critical review of the literature. Pediatrics. 1993 Oct;92(4):544-50.

Figure 1 Flow chart of search strategy. 
evidence on the effectiveness of office-based IP counselling encouraging behaviour changes and prevention of injuries to children $<5$ years of age.

\section{METHODS}

\section{Study team}

Four authors and one study research assistant completed the review. All authors have had recent leadership roles in the AAP's Council on Injury, Violence and Poison Prevention, and each has contributed extensively to the IP literature.

\section{Article selection}

The goal of the project was to review all evaluations of the effectiveness of office-based paediatric IP counselling research studies that were published after Bass' article. ${ }^{15}$ Using Google Scholar, the study team identified all peer-reviewed articles published between 1 July 1991 and 1 June 2016 that referenced the Bass article. Since Bass' article was instrumental in showing patient behaviour change and injury reduction following paediatric office counselling, we began with all published studies that cited the report by Bass. All articles chosen were initially vetted by one research assistant to ensure they met inclusion criteria. These criteria included: (1) an intervention for a family with a child $<5$ years of age; (2) an unintentional injury mechanism addressed during counselling; (3) one or more mechanisms recommended to be discussed for children $<5$ years in the 2007 AAP
Policy Statement; (4) counselling occurring in the office setting; (5) an assessment of an outcome (eg, change in knowledge, behaviour or injury occurrences); and (6) English-language publication. One-time behavioural surveys and other observational study designs were not included. Age less than or equal to 5 years was chosen in order to focus on preschoolers who spend a significant amount of time at home. Also, children of this age commonly attend well-child visits with their parent/ guardian, and these caregivers are the ones that would primarily be making the behaviour change after receiving counselling. Full manuscripts of those identified by the research assistant were then reviewed by the four authors to ensure that all inclusion criteria were met and to resolve any discrepancies. Conflicts between reviewers on design or outcome were discussed as a team and resolved by consensus. After the initial articles were chosen, references of all articles that met inclusion were reviewed, and they went through the same process as above.

In order to be as inclusive as possible, the study team also performed a literature review using key search terms to attempt to ensure that all office-based IP counselling papers with an outcome that met our inclusion criteria were reviewed. The key words chosen included: (A) counseling or 'anticipatory guidance', (B) unintentional injury or safety, (C) child or childhood or pediatric or paediatric or children and (D) office-based. All duplicate articles were deleted, and the remaining articles were independently reviewed by the authors to

Table 1 Study characteristics and outcomes

\begin{tabular}{|c|c|c|c|c|c|c|}
\hline & \multicolumn{3}{|c|}{ Study characteristics } & \multicolumn{3}{|c|}{ Outcomes assessed } \\
\hline & Controlled & $\begin{array}{l}\text { Randomised } \\
\text { intervention }\end{array}$ & $\begin{array}{l}\text { Investigators } \\
\text { blinded }\end{array}$ & $\begin{array}{l}\text { Educational } \\
\text { (including } \\
\text { reported } \\
\text { behaviours) }\end{array}$ & $\begin{array}{l}\text { Behavioural } \\
\text { (observed) }\end{array}$ & Injuries \\
\hline Clamp and Kendrick ${ }^{16}$ & $\mathrm{x}$ & & & $\mathrm{x}$ & & \\
\hline Kendrick et al ${ }^{17}$ & $x$ & $x$ & $\mathrm{x}$ & $x$ & & $\mathrm{x}$ \\
\hline Gielen et $a l^{18}$ & $x$ & $x$ & & $x$ & $x$ & \\
\hline Nansel et $a l^{19}$ & $x$ & $x$ & & $x$ & & \\
\hline Mock et $a^{20}$ & $x$ & & & $x$ & & \\
\hline Tan et $a l^{21}$ & $x$ & $x$ & $\mathrm{x}$ & $x$ & & $x$ \\
\hline Watson et $a l^{22}$ & $\mathrm{x}$ & $\mathrm{x}$ & & $\mathrm{x}$ & $x$ & $\mathrm{x}$ \\
\hline McDonald et $a l^{23}$ & $x$ & $\mathrm{x}$ & & $x$ & & \\
\hline Kendrick et $a l^{24}$ & $x$ & $x$ & $x$ & $x$ & & \\
\hline Sangvai et $a l^{25}$ & $x$ & $x$ & $x$ & & $\mathrm{x}$ & $\mathrm{x}$ \\
\hline Pless et $\left.a\right|^{26}$ & $x$ & $x$ & & $\mathrm{x}$ & $x$ & \\
\hline Nansel et $a l^{27}$ & $x$ & $x$ & $x$ & $x$ & & \\
\hline Powell et $a l^{28}$ & $x$ & $x$ & & $x$ & & \\
\hline van Beelen et a $\left.\right|^{29}$ & $x$ & $x$ & & $x$ & & \\
\hline Franz et $a l^{30}$ & & & & $x$ & & \\
\hline Brixey et $\left.a\right|^{31}$ & $\mathrm{X}$ & & & & & $\mathrm{X}$ \\
\hline
\end{tabular}


Table 2 Target injuries, sample size and effects demonstrated

\begin{tabular}{|c|c|c|c|c|}
\hline & Target safety behaviours & Sample size & Positive effect demonstrated & No effect demonstrated \\
\hline Clamp and Kendrick ${ }^{16}$ & $\begin{array}{l}\text { Fire, electric outlet, sharp } \\
\text { object, poison safety and } \\
\text { injuries from doors }\end{array}$ & 165 & $\begin{array}{l}\text { Use of fireguards, smoke alarms, } \\
\text { electric outlet covers, locks on } \\
\text { cupboards and door slam devices } \\
\text { Safe practice in storage of sharp } \\
\text { objects and medicines, and safety } \\
\text { regarding windows, fireplaces, } \\
\text { sockets, smoke alarms and door } \\
\text { slams }\end{array}$ & $\begin{array}{l}\text { No differences in } \\
\text { proportion of families } \\
\text { regarding stairway safety } \\
\text { behaviour or storage of } \\
\text { cleaning materials. }\end{array}$ \\
\hline Kendrick et al $\left.\right|^{17}$ & $\begin{array}{l}\text { Any unintentional injury } \\
\text { seen at an emergency } \\
\text { department. } \\
\text { Equipment provided: } \\
\text { stair gates, fireguards, } \\
\text { cupboard locks and } \\
\text { smoke alarms. }\end{array}$ & $\begin{array}{l}1124 \text { intervention. } \\
1028 \text { control. }\end{array}$ & $\begin{array}{l}\text { More confident in dealing with } \\
\text { choking incidents and more likely } \\
\text { to know correct action for bleach } \\
\text { ingestion. }\end{array}$ & $\begin{array}{l}\text { No difference in injury } \\
\text { frequencies. } \\
\text { No difference in secondary } \\
\text { outcome measures. } \\
\text { No differences between } \\
\text { in scores for perceptions } \\
\text { of risk of injury or risk of } \\
\text { hazards. }\end{array}$ \\
\hline Gielen et $a l^{18}$ & $\begin{array}{l}\text { Hot water, smoke alarm, } \\
\text { baby walker, stair, poison } \\
\text { and safety. }\end{array}$ & $>196$ & & $\begin{array}{l}\text { No differences in } \\
\text { knowledge or behaviours. }\end{array}$ \\
\hline Nansel et $a l^{19}$ & $\begin{array}{l}\text { Car, burn/fire, drowning, } \\
\text { poison and fall }\end{array}$ & $\begin{array}{l}-85 \text { intervention } \\
89 \text { control }\end{array}$ & $\begin{array}{l}\text { Greater adoption of home and car } \\
\text { safety behaviours among group } \\
\text { receiving tailored information }\end{array}$ & \\
\hline Mock et $a l^{20}$ & $\begin{array}{l}\text { Bike helmets, hot water } \\
\text { temperature, smoke } \\
\text { detector, child passenger } \\
\text { and road traffic safety }\end{array}$ & $\begin{array}{l}1124 \text { children } \\
\text { before counselling } \\
625 \text { after it had } \\
\text { been given }\end{array}$ & $\begin{array}{l}\text { Increase in mean per cent safe } \\
\text { response scores } \\
\text { Improved use of bicycle helmets in } \\
\text { middle and lower socioeconomic } \\
\text { groups } \\
\text {-Increased use of car seats by } \\
\text { children aged 0-4years in lower } \\
\text { socioeconomic group }\end{array}$ & $\begin{array}{l}\text { Even with improvement, } \\
\text { overall use of safety } \\
\text { devices suboptimal even } \\
\text { after counselling with } \\
\text { discrepancies between } \\
\text { socioeconomic strata } \\
\text { Minimal to no changes } \\
\text { seen regarding knowledge } \\
\text { on crossing roads safely, } \\
\text { burn and prevention }\end{array}$ \\
\hline Tan et $a l^{21}$ & - Infant walkers & $>708$ & $\begin{array}{l}\text { Decreased walker use after } \\
\text { intervention }\end{array}$ & $\begin{array}{l}\text { No difference in walker } \\
\text { injuries between groups }\end{array}$ \\
\hline Watson et $a l^{22}$ & $\begin{array}{l}\text { Falls, fires, poisoning and } \\
\text { window falls }\end{array}$ & $\begin{array}{l}3428 \text { families ( } 3995 \\
\text { children) }\end{array}$ & $\begin{array}{l}\text { More likely to be safe with stairs, } \\
\text { smoke alarms, windows and } \\
\text { storage of cleaning products/ } \\
\text { sharp objects }\end{array}$ & $\begin{array}{l}\text { Intervention group had } \\
\text { higher attendance rate for } \\
\text { injury in primary care, but } \\
\text { no other differences injury } \\
\text { outcomes seen }\end{array}$ \\
\hline McDonald et $a^{23}$ & $\begin{array}{l}\text { Smoke alarm, poison, } \\
\text { fall and child passenger } \\
\text { safety }\end{array}$ & $\begin{array}{l}-70 \text { intervention } \\
74 \text { control }\end{array}$ & $\begin{array}{l}\text { More knowledge about } \\
\text { inappropriateness of young children } \\
\text { riding in the front seat of a car, less } \\
\text { likely to believe that teaching a } \\
\text { child to mind you is the best way } \\
\text { to prevent injuries and more likely } \\
\text { to report that they have syrup of } \\
\text { ipecac and know how to use it* }\end{array}$ & $\begin{array}{l}\text { No difference in groups for } \\
\text { seven other safety items } \\
\text { and three other belief } \\
\text { items }\end{array}$ \\
\hline Kendrick et $a l^{24}$ & Baby walker safety & $\begin{array}{l}539 \text { intervention } \\
635 \text { control }\end{array}$ & $\begin{array}{l}\text { Less likely to: own or use walker, } \\
\text { plan to use walker with their next } \\
\text { child or agree that walkers keep } \\
\text { children safe } \\
\text { Some evidence they were less likely } \\
\text { to recommend walker to friend or } \\
\text { agree that they help children to } \\
\text { walk more quickly }\end{array}$ & \\
\hline Sangvai et $a l^{25}$ & $\begin{array}{l}\text { Child safety seats } \\
\text { Smoke detectors } \\
\text { Safe storage of } \\
\text { hazardous substances } \\
\text { and poisons } \\
\text { Tap water temperature } \\
\text { Gun storage }\end{array}$ & $\begin{array}{l}160 \text { intervention } \\
159 \text { control }\end{array}$ & $\begin{array}{l}\text { More likely to have: smoke } \\
\text { detectors present and functional } \\
\text { and hazardous substances not } \\
\text { found in low cabinets }\end{array}$ & $\begin{array}{l}\text { No difference in rate of } \\
\text { medically attended injuries }\end{array}$ \\
\hline Pless et $a^{26}$ & $\begin{array}{l}\text { Knowledge and } \\
\text { behaviours related to } \\
\text { window blind cords } \\
\text { and cords from clothing } \\
\text { drawstrings }\end{array}$ & $\begin{array}{l}369 \text { intervention } \\
439 \text { control }\end{array}$ & & $\begin{array}{l}\text { No difference in behaviour } \\
\text { (cutting cords) or injury } \\
\text { related to window } \\
\text { blind cords or clothing } \\
\text { drawstrings }\end{array}$ \\
\hline
\end{tabular}


Table 2 Continued

\begin{tabular}{|c|c|c|c|c|}
\hline & Target safety behaviours & Sample size & Positive effect demonstrated & No effect demonstrated \\
\hline Nansel et $\left.a\right|^{27}$ & $\begin{array}{l}\text { Car, burn, fall, poison, } \\
\text { airway obstruction and } \\
\text { drowning }\end{array}$ & 305 (three arms) & $\begin{array}{l}\text { More likely to adopt new injury } \\
\text { prevention behaviour }\end{array}$ & \\
\hline Powell et $a l^{28}$ & $\begin{array}{l}\text { Home-falls, burns and } \\
\text { drowning }\end{array}$ & $>371$ & $\begin{array}{l}\text { Increase in education in both } \\
\text { groups following discussion }\end{array}$ & \\
\hline van Beelen et $a l^{29}$ & $\begin{array}{l}\text { Falls, poisoning, } \\
\text { drowning and burns }\end{array}$ & $>1292$ & $\begin{array}{l}\text { Increase in safe behaviour for } \\
\text { stairs, storage of cleaning products, } \\
\text { bathing of child, drinking of hot } \\
\text { fluids, using rear hotplates and } \\
\text { composite safety score }\end{array}$ & $\begin{array}{l}\text { No significant differences } \\
\text { for other specific } \\
\text { behaviours }\end{array}$ \\
\hline Franz et $a l^{30}$ & $\begin{array}{l}\text { Crib, hot water and child } \\
\text { passenger safety }\end{array}$ & $\begin{array}{l}84 \text { (pretest and } \\
\text { post-test) }\end{array}$ & Increased knowledge & \\
\hline Brixey et $\left.a\right|^{31}$ & Any unintentional injury & $>1368$ & & $\begin{array}{l}\text { No difference in groups; } \\
\text { very small sample of } \\
\text { injured patients }\end{array}$ \\
\hline
\end{tabular}

Since the publication of McDonald et $\mathrm{al}^{23} 2005$, syrup of ipecac has no longer been recommended to be used by parents.

assess for eligibility and discussed by the team to alleviate any controversies. A complete flow chart of the search strategy can be found in figure 1 .

\section{Determination of study characteristics and outcomes}

After the literature search was completed, the study characteristics (whether the study was controlled, randomised and/or blinded) and outcomes assessed (injuries, behaviour changes and/or education changes) were summarised. Also summarised were the target safety behaviours, the sample size and any demonstrated effect.

\section{RESULTS}

From the search of articles that referenced the Bass article, we identified 14 studies that met our inclusion criteria, and from our keyword search, we identified two additional articles that met inclusion criteria. ${ }^{16-31}$ Of the 16 articles, 12 were randomised controlled trials, 3 were non-randomised trials and 1 was a pretest and posttest study (table 1). The investigators were blinded in five of the studies, but participants were not blinded in any. Fourteen studies measured a change in knowledge or reported behaviour change, four included observed behaviour change and five measured changes in injury outcomes. The most common topics covered were fall prevention, poison prevention, burn prevention, fire safety and traffic safety (table 2 ).

For fall prevention, eight of the studies demonstrated positive changes on knowledge or behaviour, while three studies did not. Similarly, positive changes for poison prevention were seen in seven studies, one did not demonstrate any changes in education or behaviour and one showed both positive and no effect for different aspects of poisoning. Regarding burn prevention and fire safety (including hot water safety, smoke alarms, fireguards and fireplaces), positive changes in knowledge and/or behaviours were seen in seven of the studies, while no effects were demonstrated in four of the studies that measured these outcomes. Changes in traffic safety knowledge or behaviour were seen in four of the studies, with one additional study showing positive effects for some aspects of road traffic safety but minimal to no change with other aspects. Overall, 13 of the 16 studies had positive effects demonstrated for certain outcomes, while 10 showed no differences between study groups for other outcomes.

\section{DISCUSSION}

In this update to the 1991 Bass article, we found increasingly rigorous evidence of the benefit of office-based IP counselling on the promotion of IP knowledge, self-reported safe behaviours and injury outcomes for children aged $<5$ years. In particular, there was increased knowledge and self-reported safe behaviours surrounding fire and burn safety (fireguards, smoke alarms and electric outlets), home safety (locks on cupboards, door slam devices, windows, stairs, walkers, bathing and cribs) and road traffic safety (helmets, car seats and seat belts). Notably, nearly all the studies focused on knowledge and behaviours and not injury outcomes, the gold standard for injury-related research.

Our study is subject to several limitations. Perhaps most important is the possibility of publication bias. Just as in all reviews, negative studies are more likely to remain unpublished. Investigators may be more motivated to write, and journals may be more interested in publishing articles that found an effect of IP counselling. To the extent that this is true in this case, our work may be biased towards reporting a more favourable effect of IP counselling than truly exists. It is also possible that we did not find all eligible studies in our search. We attempted to prevent this through a systematic approach, including the use of broad search terms initially and inspection of the references of papers. We also reviewed all articles that cited the original Bass paper. We also limited our search to English language publications that may have excluded articles of value 
from non-English journals. We only reviewed studies that provided evidence of IP counselling for children aged $\leq 5$ years.

We conclude that, in the past quarter century since the review of the same topic by Bass, there is accumulating evidence of the benefit of IP counselling done in the clinical setting on the knowledge, self-reported safety behaviours and injury outcomes among children aged $<5$ years. Given the magnitude of the problem of childhood injury and its contribution to child morbidity and mortality, clinicians who care for children should continue to provide such counselling to protect their patients. Further research should be undertaken to better refine what aspects of counselling are most effective for different injury types.

Contributors All authors contributed to conception and design, contributed to data acquisition and contributed to data analysis. MRZ and MAG drafted manuscript. All authors critically revised manuscript, gave final approval and agree to be accountable for all aspects of work ensuring integrity and accuracy.

Funding The authors have not declared a specific grant for this research from any funding agency in the public, commercial or not-for-profit sectors.

Competing interests None declared.

Patient consent Not required.

Provenance and peer review Not commissioned; externally peer reviewed.

Open access This is an open access article distributed in accordance with the Creative Commons Attribution Non Commercial (CC BY-NC 4.0) license, which permits others to distribute, remix, adapt, build upon this work non-commercially, and license their derivative works on different terms, provided the original work is properly cited and the use is non-commercial. See: http://creativecommons.org/ licenses/by-nc/4.0/

(c) Article author(s) (or their employer(s) unless otherwise stated in the text of the article) 2018. All rights reserved. No commercial use is permitted unless otherwise expressly granted.

\section{REFERENCES}

1. Centers for Disease Control and Prevention. 10 Leading causes of injury deaths by age group highlighting unintentional injury deaths. 2015 https://www.cdc.gov/injury/wisqars/LeadingCauses.html

2. Centers for Disease Control and Prevention. CDC vital signs. Child injury infographic. 2012 http://www.cdc.gov/vitalsigns/childinjury/ infographic.html (accessed 16 Jan 2018).

3. Danseco ER, Miller TR, Spicer RS. Incidence and costs of 19871994 childhood injuries: demographic breakdowns. Pediatrics 2000;105.E27.3.

4. Gardner HG. American Academy of Pediatrics Committee on Injury, Violence, and Poison Prevention. Office-based counseling for unintentional injury prevention. Pediatrics 2007;119:202-6.

5. American College of Surgeons. Statement on firearm injuries. http:// www.facs.org/fellows_info/statements/st-12.html (accessed 8 Sep 2013).

6. US Preventative Services Task Force. Child and adolescent recommendations. http://www.uspreventiveservicestaskforce.org/ tfchildcat.htm\#injury (accessed 8 Sep 2013).

7. Yarnall KS, Pollak KI, Østbye T, et al. Primary care: is there enough time for prevention? Am J Public Health 2003;93:635-41.
8. Belamarich PF, Gandica R, Stein RE, et al. Drowning in a sea of advice: pediatricians and American Academy of Pediatrics policy statements. Pediatrics 2006;118:e964-e978.

9. Wright MS. Pediatric injury prevention. Preparing residents for patient counseling. Arch Pediatr Adolesc Med 1997;151:1039-43.

10. Gielen AC, McDonald EM, Omaki E, et al. A smartphone app to communicate child passenger safety: an application of theory to practice. Health Educ Res 2015;30:683-92.

11. Williams J1, Nansel TR, Weaver NL, Tse J. Safe n' sound: an evidence-based tool to prioritize injury messages for pediatric health care. Fam Community Health 2012;35:212-24.

12. Shields WC, McDonald EM, McKenzie L, et al. Using the pediatric emergency department to deliver tailored safety messages: results of a randomized controlled trial. Pediatr Emerg Care 2013;29:628-34.

13. Gittelman MA, Denny S, Anzeljc S, et al. A pilot quality improvement program to increase pediatrician injury anticipatory guidance. $J$ Trauma Acute Care Surg 2015;79(Suppl 1):S9-14.

14. American Academy of Pediatrics (AAP). TIPP - The Injury Prevention Program. https://patiented.solutions.aap.org/handout-collection. aspx? categoryid=32033 (accessed 1 Feb 2018).

15. Bass JL, Christoffel KK, Widome M, et al. Childhood injury prevention counseling in primary care settings: a critical review of the literature. Pediatrics 1993;92-544-50.

16. Clamp M, Kendrick D. A randomised controlled trial of general practitioner safety advice for families with children under 5 years. BMJ 1998;316:1576-9.

17. Kendrick D, Marsh P, Fielding K, et al. Preventing injuries in children: cluster randomised controlled trial in primary care. BMJ 1999;318:980-3.

18. Gielen AC, Wilson ME, McDonald EM, et al. Randomized trial of enhanced anticipatory guidance for injury prevention. Arch Pediatr Adolesc Med 2001;155:42-9.

19. Nansel TR, Weaver N, Donlin M, et al. Baby, Be Safe: the effect of tailored communications for pediatric injury prevention provided in a primary care setting. Patient Educ Couns 2002;46:175-90.

20. Mock C, Arreola-Risa C, Trevino-Perez R, et al. Injury prevention counselling to improve safety practices by parents in Mexico. Bull World Health Organ 2003;81:591-8.

21. Tan NC, Lim NM, Gu K. Effectiveness of nurse counselling in discouraging the use of the infant walkers. Asia Pac J Public Health 2004:16:104-7.

22. Watson M, Kendrick D, Coupland C, et al. Providing child safety equipment to prevent injuries: randomised controlled trial. BMJ 2005;330:178.

23. McDonald EM, Solomon B, Shields W, et al. Evaluation of kioskbased tailoring to promote household safety behaviors in an urban pediatric primary care practice. Patient Educ Couns 2005;58:168-81.

24. Kendrick D, Illingworth R, Woods A, et al. Promoting child safety in primary care: a cluster randomised controlled trial to reduce baby walker use. Br J Gen Pract 2005;55:582-8.

25. Sangvai S, Cipriani L, Colborn DK, et al. Studying injury prevention: practices, problems, and pitfalls in implementation. Clin Pediatr 2007;46:228-35

26. Pless IB, Hagel B, Patel $\mathrm{H}$, et al. Preventing product-related injuries: a randomized controlled trial of poster alerts. Can J Public Health 2007;98:271-5.

27. Nansel TR, Weaver NL, Jacobsen HA, et al. Preventing unintentional pediatric injuries: a tailored intervention for parents and providers. Health Educ Res 2008;23:656-69.

28. Powell EC, Malanchinski J, Sheehan KM. A randomized trial of a home safety education intervention using a safe home model. $J$ Trauma 2010;69(4 Suppl):S233-36.

29. van Beelen ME, Beirens TM, den Hertog P, et al. Effectiveness of web-based tailored advice on parents' child safety behaviors: randomized controlled trial. J Med Internet Res 2014;16:e17.

30. Franz S, McMahon PM, Calongne L, et al. Anticipatory guidance through DVD. Clin Pediatr 2014;53:256-60.

31. Brixey SN, Weaver NL, Guse CE, et al. The impact of behavioral risk assessments and tailored health information on pediatric injury. Clin Pediatr 2014;53:1383-9. 